\title{
Evaluation of the Varieties of Indian Gooseberry for Resistance against Penicillium islandicum
}

\author{
A. K. Saini, R. S. Chauhan*, Ashwani Kumar, Narender Singh and Satish Kumar \\ Chaudhary Charan Singh Haryana Agricultural University, Hisar, Haryana-125 004, India \\ *Corresponding author
}

\section{A B S T R A C T}

\section{Keywords \\ Penicillium islandicum, Indian gooseberry, Resistance, Susceptibility, Varieties}

Article Info

Accepted:

20 August 2019

Available Online:

10 September 2019
Present investigations were undertaken at Chaudhary Charan Singh Haryana Agricultural University, Hisar. Aonla or Indian gooseberry, Emblica officinalis Garten, is an important horticulture crop of India. It is a rich source of vitamin $\mathrm{C}$ and used in various ayurvedic medicines. Penicillium islandicum, which was, earlier, a minor disease, but now become a major disease of Inadian gooseberry. The present study revealed that resistance and susceptibility against the blue mould rot (Penicillium islandicum) disease can be observed among the varieties of E. officinalis suggesting that the resistant ones should be preferred for further plantation activities to avoid the frequent damage and losses caused by the disease. Nine commercial varieties (Desi, Hathizool, Kanchan, Krishna, Chakaiya, Banarsi, NA-7, NA-9, NA-10) were also tested for their comparative resistance against Penicillium islandicum. In varietal screening against blue mould rot, least disease intensity was recorded in Desi $(2.67 \%)$ and Kanchan $(3.33 \%)$ while maximum disease intensity was observed in Chakaiya (50.00\%) and Banarsi (49.33\%).

\section{Introduction}

Indian gooseberry is an important indigenous crop of Indian subcontinent which is used as alternative medicine, health foods and in herbal products (Nayak et al., 2012). Indian gooseberry fruit contains different essential nutrients viz., carbohydrates, proteins, phenol, calcium, phosphorus, zinc, and vitamin $\mathrm{B}$ etc. It is a rich source of vitamin $C$ ranging from $400-1300 \mathrm{mg} / 100 \mathrm{gm}$ pulp and vitamin B 300 mg/100 gm pulp (Singh, 2006; Kore et al., 2013). Its constituents serve as important source of food and medicine (Kumar and Singh, 2002). Banarasi, Chakaiya, Krishna, Francis (Hathijhul), Kanchan, NA-6, NA-7, Anand-1, 2, 3 are some of the commercially cultivated varieties of aonla in India. (Goyal et al., 2008; Singh et al., 2009).

Tiwari et al., (2008) reported field screening of aonla varieties against Deudorix isocrates 
(Fabr.). The maximum $43.70 \%$ fruit damage was observed in NA-7 (Narendra-7) and the minimum $33.60 \%$ was observed in Chakaiya. The order of susceptibility of different varieties was NA-7 (43.70\%), Kanchan (41.25\%), NA-6 (40.80\%), NA-10 (38.40\%) and Chakaiya (33.60\%). Similar observations were also reported by Padmavati et al., (2002). Meshram and Soni (2011) screened certain varieties for resistance to insect pests and diseases in central India. They reported that ten varieties of Emblica officinalis Gaertn. including Kanchan, Chakaiya, Francis, NA-7, NA-10 (Narendra 10), Anand-1, Anand-2, Krishna, Hatizola (Local) and Local-wild were screened against insect pests \{gall forming insect (Betousa stylophora Swinhoe), leaf roller (Garcillaria acidula Forster), bark eating caterpillar (Indrabela quadrinotata walker) $\}$ and diseases that is vascular wilt (Fusarium oxysporum f.sp., albedinis Killian and Maire), fruit disease (Alternaria sp.). The results revealed that variety NA-10 followed by Kanchan was found to be least preferred by B. stylophora, G. acidula, I.quadrinotata and Alternaria sps. in clonal seed orchards, whereas variety Hatizola (Local) followed by Francis showed less incidence of Fusarium oxysporum in nursery stage.

\section{Materials and Methods}

Nine commercial varieties (Desi, Hathizool, Kanchan, Krishna, Chakaiya, Banarsi, NA-7, NA-9, NA - 10) were tested for their comparative susceptibility to Penicillium islandicum. The fruits were inoculated with the pathogen by well method (Granger and Horne, 1924). The fruit was punctured with cork borer up to a depth $0.5 \mathrm{~mm}$ and then inoculated with disc of inoculums and plugging back with the removed portion of fruit. All treatments were replicated thrice and each replication had ten fruits. The disease intensity was determined by calculating the per cent of rotted tissue in the test fruit. Every fruit was weighed after storage period. The rotten portion of the fruits was removed with the help of a knife and the remaining part of the fruit was again weighed. The loss of weight of each fruit was determined by subtracting the final weight from initial weight. The percentage of rot (disease intensity) was calculated with formula suggested by Srivastava and Tandon (1968).

$$
\begin{aligned}
& \text { Percentage of rot } \\
& \text { (Disease intensity) } \\
& (\mathrm{W}-\mathrm{w}) \\
& =\text {-------- } \times 100
\end{aligned}
$$

Where, $\mathrm{W}$ is the weight of the fruit without removing the rotten portion and

$\mathrm{w}$ represent the weight of the fruit after removal of the diseased portion.

\section{Results and Discussion}

The varietal reaction of nine varieties against blue mould rot was recorded in per cent disease intensity and presented in Table 3 and Fig 1. All the varieties showed different behavior to the disease. The intensity of the disease varied from 2.67 to 50.00 per cent in different varieties. The varieties Chakaiya and Banarsi contracted 50.00 and 49.33 per cent disease respectively, therefore considered highly susceptible. However, the disease severity was 2.67 per cent in Desi (seedling) and 3.33 per cent in Kanchan, hence were termed as resistant for further studies.

Present investigations on the reaction of different varieties of Indian gooseberry to blue mould rot indicated that the per cent disease intensity varied from 2.67 to 50 per cent. Maximum disease intensity was recorded in Chakaiya $(50.00 \%)$ and Banarsi $(49.33 \%)$ and minimum in Desi $(2.67 \%)$ and Kanchan (3.33 \%). Meshram and Soni (2011) and Tiwari et al., (2008) also reported that aonla 
variety NA-10 (Narendra-10) followed by Kanchan was found to be least preferred by insect pests and diseases. The present study revealed that, resistance and susceptibility against the diseases can be observed among the varieties of $E$. officinalis suggesting that the resistant ones should be preferred for further plantation activities to avoid the frequent damage and losses caused by the diseases

Table.1 Evaluations of different varieties of Indian gooseberry against blue mould rot

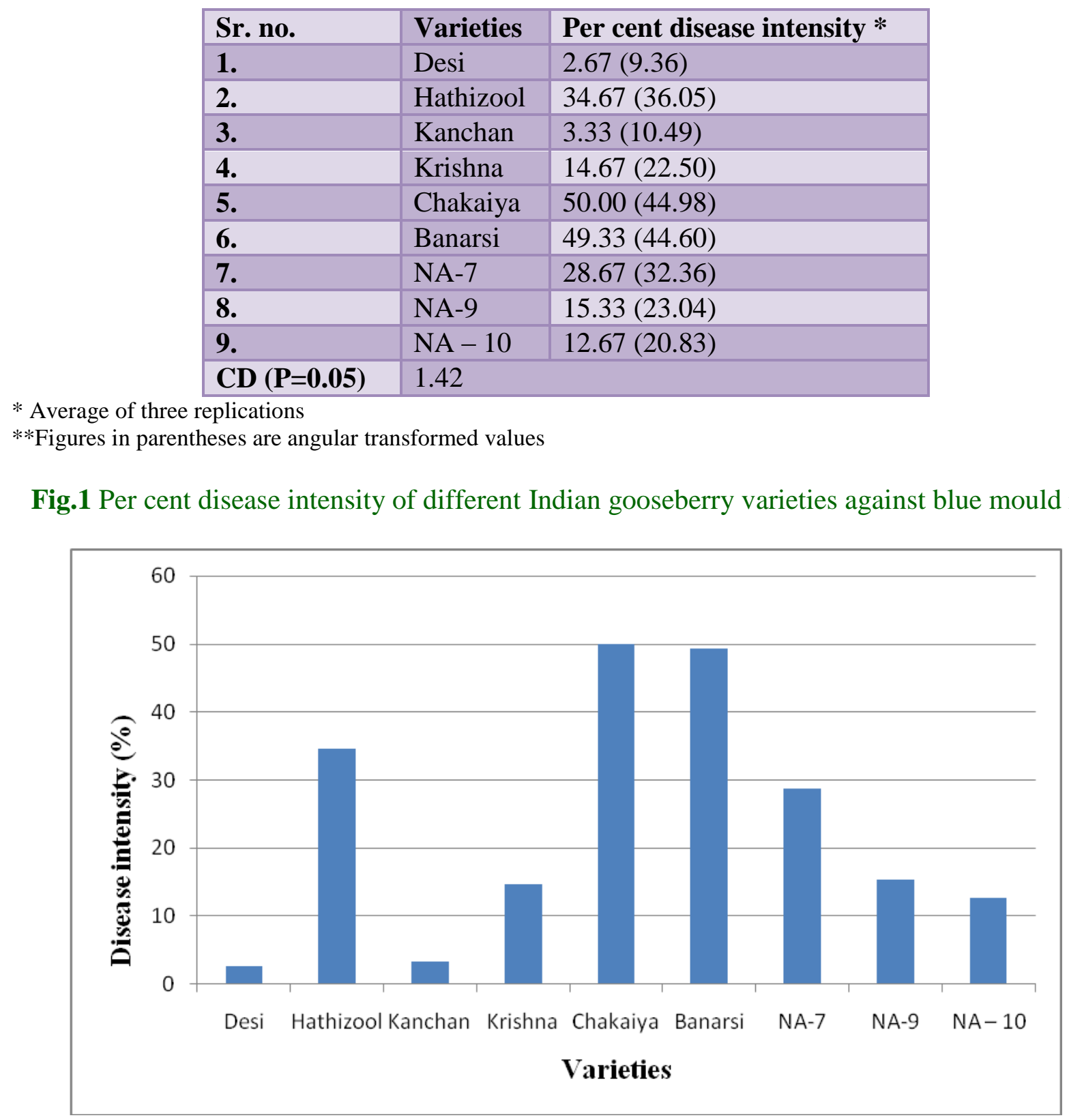


In varietal screening of Indian gooseberry against blue mould rot, least disease intensity was recorded in Desi (2.67\%) and Kanchan $(3.33 \%)$ while maximum disease intensity was observed in Chakaiya (50.00\%) and Banarsi $(49.33 \%)$.

\section{Acknowledgement}

This investigations on "Studies on blue mould rot of aonla (Emblica officinalis Goerth.) caused by Penicillium islandicum (Sopp.)" are undertaken in the Department of Plant Pathology, College of Agricultural Chaudhry Charan Singh Haryana Agriculture University, Hisar.

\section{References}

Goyal, R. K.; Patil, R. T.; Kingsly, A. R. P.; Walia, H. and Kumar, P. 2008. Status of Post Harvest Technology of Aonla in India-A Review. American Journal of Food Technology, 3 (1):13-23.

Granger, K. and Horne, A. S. 1924. A method of inoculating the apples. Annals of Botany. 38: 212-215.

Kore, V.t., Devi, H.L. and Kabir, J. 2013. Packaging, storage and value addition of aonla - an under utilized fruit in India. Fruits 68: 169-173.

Kumar, S. and Singh, I. S. 2002. Physiochemical studies of various cultivars of aonla fruits. Progressive Horticulture. 34(1): 102-104.

Meshram, P. S. and Soni, K. K. 2011. Screening of certain varieties of Emblica officinalis Gaertn. For resistence to insect pests and diseases in central India. Journal of Horticulture and Forestry Vol. 3(6): pp. 190-194.

Nayak, P., Tandon, D. K. and Bhatt, D. K. 2012. Study on changes of nutritional organoleptic quality of flavoured candy prepared from aonla (Emblica officinalis G.) during storage. International Journal of Nutrition and Metabolism. 7: 100-106.

Padmavati, C., Kumar, S. and Kumar, S. 2002. Changing status of Virachola Isocrates (Fabr.) in different varities of aonla. Indian Journal of Agroforestry. 4(2): 148-150.

Singh, B. P. 2006. Scintific storage of nutritious aonla. Phal-Phool. (Sept.Oct.): 8-10.

Singh, S., Singh, A. K., Joshi, H. K., Bagle, B. G. and Dhandar, D. G. 2009. Evaluation of packages for transportation and storability on aonla (Emblica officinalis Gaertn.) under semi arid environment of western India. Journal of Food Science and Technology. 46: 127-131.

Srivastava, M. P. And Tandon, R. N. 1968. Influence of temperature on Botryodiplodia rot of citrus and sapodilla. Indian Photopathology. 21: 195-197.

Tiwari, A. K., Mishra, P. and Tiwari, S. C. 2008. Field screening of some cultivars of aonla (Emblica officinalis Gaert.) against Deudorix isocrates (Fabr.). New Agriculturist.1 9(1,2): 101-103.

\section{How to cite this article:}

Saini, A. K., R. S. Chauhan, Ashwani Kumar, Narender Singh and Satish Kumar 2019. Evaluation of the Varieties of Indian Gooseberry for Resistance against Penicillium islandicum. Int.J.Curr.Microbiol.App.Sci. 8(09): 2086-2089. doi: https://doi.org/10.20546/ijcmas.2019.809.240 